ACTA SCIENTIFIC NEUROLOGY (ISSN: 2582-1121)

Volume 2 Issue 11 November 2019

Perspective

\title{
“Contemporary American Stupidity” Reviewed
}

\section{James F Welles*}

East Marion, USA

*Corresponding Author: James F Welles, East Marion, USA.

Received: October 16, 2019; Published: October 22, 2019

DOI: 10.31080/ASNE.2019.02.0120

"Contemporary American Stupidity" covers exactly what it purports to cover-the idiocy of modern American political and cultural life. Stupidity is defined as the learned inability to learn: That is-a normal, dysfunctional learning process which occurs when a schema formed by linguistic biases and social norms acts via the neurotic paradox to establish a positive feedback system which becomes first self-sustaining and then renders behavior irrelevant to the environment by carrying detached actions to maladaptive excesses. The topics dealt with in this well researched and documented article include injustice, the economy, society, foreign policy, defense, the environment, education and identity and lead to a depressing if not distressing conclusion.

If you like injustice, you will love the treatment American citizens of Japanese descent received when interned during World War II. The much hyped Constitution was a scrap of paper in the wind of war, as 127,000 people were essentially imprisoned not for what they did but who they were. The lesson was that the Constitution guarantees nothing. Ironically, this message was driven home at home while Americans were fighting and dying for justice and peace on the international scene.

The economy takes a justified beating if telling the truth about deficit spending counts as drubbing the financial establishment. The dollar is properly identified was becoming progressively worth less and less as the government spends us into bankruptcy. Nevertheless, Americans persist in believing in capitalism, al- though the model they tout has next to nothing to do with the actual functioning of the corporate dominated system which runs our lives.

Socially, we are dominated by a PC code which maintains everyone equal to everyone else. This is all well and good unless a job requires someone to do something. Welfare programs slide over any differences in groups of people, and the push now is to require reverse discrimination so as to balance out the employment picture. The problem there is that discrimination is still discrimination. Be it for a group or against another, it is still a matter of judging people by genetic criteria.

Environmentalism is touted as an answer to problems of cultural imbalance, but this leads invariably to a consideration of family structure. A consideration of test results shows that Asians out-perform whites on tests designed by whites. This complicates all social strata studies immeasurably by indicating that family values are essential to intellectual development. In addition is the tendency to embrace everyone's performance is equally good because we do not want to imply that an answer to a test question is wrong.

As for our foreign policy, it has been chronically negative since the Cold War began. We are anti- Communist. That is it. The only times we present ourselves in a positive light is when we go into a smaller country to develop it for business interests. Sad to say, we are divided between liberals who view the world in terms of preWorld War I conditions when doing nothing led to disaster. They are opposed by conservatives who view the world in terms of the Munich peace conference of 1938, when appeasement led to disaster.

Our foreign policy is enforced by our military, which is a corrupt and wasteful as any organization can be. A glance at the performance of our defense forces up to and including the Afghan war is an intellectual insult to anyone with an ounce of integrity. Meanwhile the brass struggle with the fact that ho- mosexuals appear to be as competent and efficient as straights-studies designed to demonstrate the opposite notwithstanding. 
Efforts to improve ourselves through education are always well intended by rarely successful. One of the chronic problems is that we cannot define to goals we are trying to reach. Are we trying to make everyone feel good about themselves and the system? Are we debasing the three R's by lowering our standards? The sad fact of the matter is that those who need help the most are getting the least from a system designed to gloss over its own deficiencies.

Which brings us to the ultimate consideration: Who are we? The answer is cast as an ethical imperative. Do we live up to ourselves and our professed standards? Or do we promote our image as a culture of self-limiting people trying very hard to look good? The answer lies in the fault line between rights and responsibilities. That, in turn, is presented as the ageless question of apparent progress based on broken political promises.

This trenchant review of stupidity concludes with a consideration of what must be regarded as an identity crisis. There are too many of us living beyond our means. Do we take religion too seriously or not seriously enough?.

Volume 2 Issue 11 November 2019

C) All rights are reserved by James F Welles. 